\title{
Realizm postmodernistyczny, abiektalność, wartościowanie. Korzyści z krytycznej refleksji nad postmoder- nizmem i Zagładą
}

Marta Tomczok

TEKSTY DRUGIE 2019, NR 4, S. 217-228

DOI: 10.18318/td.2019.4.13 | ORCID: 0000-0001-9512-007X

P.Cz.: [...] Rabbi, no i jakiż ja mogę mieć stosunek do historycznej powinności? Pewnie się domyślasz. Może nawet wiesz...

Rabbi: Pozostaje mi mieć tylko nadzieję, że mój siostrzeniec nie odejdzie z tego świata jako prowokator. ${ }^{1}$

Na początku XXI w. trudno zatem traktować postmodernizm jako zagrożenie dla historii, łatwiej już go nie dostrzegać - wszak jego ostrze wyraźnie stępiało. ${ }^{2}$

A jednak zbyt łatwo szydzi się z postmodernizmu aktualnej sceny artystycznej [...]. Takie całkowite odrzucenie sprawi, że nie dostrzeżemy krytycznego potencjału postmodernizmu, który - jak sądzę - także istnieje, mimo iż może okazać się trudny do zidentyfikowania. ${ }^{3}$

1 P. Czakański Sporek Mówiq̨c tak między nami..., „FA-art” 1993 nr 12/13, S. 122.

2 T. Wiślicz Historiografia polska 1989-2009. Bardzo subiektywne podsumowanie, "Przegląd Humanistyczny” 2010 nr 5/6, s. 39.

3 A. Huyssen Nad mapq postmodernizmu, przeł. J. Margański, w: Postmodernizm. Antologia przekładów, wyb., oprac., przedm. R. Nycz, Wydawnictwo Baran i Suszczyński, Kraków 1998, s. 458.
Marta Tomczok, badaczka Zagłady i jej odniesień kulturowych, adiunkt na Wydziale Filologicznym Uniwersytetu Śląskiego, redaktor naczelna rocznika „Narracje o Zagładzie”. Autorka książek: Trofea wyobraźni. O prozie Leo Lipskiego (2011), Metonimie Zagłady. O polskiej prozie lat 1987-2012 (2013), Czyja dzisiaj jest Zagłada? Retoryka - ideologia - popkultura (2017). Artykuły i recenzje publikowała m.in. w "Historyce Studiach Metodologicznych”, „Tekstach Drugich", Pamiętniku Literackim,, „Zagładzie Żydów. Studiach i Materiałach". Interesuje się wpływem nowych metodologii na studia o Zagładzie i innych ludobójstwach, refleksją krytyczną nad estetykami uznanymi za minione (postmodernizm), nowym animizmem oraz historią środowiskową węgla. 
Czy jednak powinniśmy się temu [banalizacji postmodernizmu - przyp. M.T.] poddawać? Pomijając fakt, że i tak w tej wojnie poszliśmy na zbyt wiele kompromisów, samo pojęcie postmodernizmu nie straciło chyba swojej mocy wyjaśniającej czy wręcz krytycznej. ${ }^{4}$

D ok 2000 zmienił nie tylko wszystko, co dotąd myśleliśmy o własnej Whistorii. Odmienił także polski postmodernizm. Kilka lat temu, chcąc zrozumieć fenomen oddziaływania Sąiadów Jana Tomasza Grossa na społeczeństwo w Polsce i jego literaturę, pomyślałam, że można by go wyrazić takim oto zdaniem: po Grossie niepodobna napisać drugich Tworek. Miało ono oznaczać, że konfrontowanie się z masakrą, do jakiego zmusił nas autor Strachu, trwale odmieniło pełne solidarności i wzniosłości opowieści o Zagładzie, zmieniając je w opowieści wypełnione okrucieństwem i lękami. Chodziło w tym sformułowaniu nie tyle o wytknięcie narracjom spod znaku powieści Bieńczyka nadmiernej elegancji czy pasywności, ale o zaznaczenie, że ten rodzaj pisania nie wytrzymał próby czasu, jest nieaktualny, skończył się w jednej chwili. Dzisiaj położyłabym akcent nie na to, co nastąpiło po Grossie, ale na ów fatalny moment, który zatrzymał postmodernizm, skupiony wokół dramatów pierwszej połowy XX wieku, w pół obrotu; a zatem nie na to, co zmienił Gross w sferze postmodernistycznej estetyki, ale na to, dlaczego w ogóle postmodernizm poddał się tej zmianie.

Podzielam tym samym stanowisko Hala Fostera dotyczące odroczonych skutków pewnych działań, a szczególnie działań związanych ze sztuką i krytyką kultury ${ }^{5}$. Jednak zamiast do awangardy będę je odnosiła do postmodernizmu, przyjmując, że on także jest nachträglich. Skoro zresztą: „znaczące działania i dyskursy postmodernizmu pojawiły się nie tyle jako zerwanie z podstawowymi praktykami i dyskursami nowoczesności, ile wobec nich nachträglich"6. Drugie z inspirujących mnie założeń Fostera dotyczy krytycznego i użytkowego potencjału postmodernizmu, sprzyja więc refleksji na temat wartościowania. I to zarówno w wymiarze podstawowym, odnoszącym się do fundamentalnych przesunięć w obrębie krytyki całego nurtu (jak wynika z mott, widzianego dziś jako zjawisko banalne, nieważne, zaprzeszłe, ograniczone, oczekujące co najwyżej na rekapitulację, odpowiednie dla mało

4 H. Foster Powrót Realnego. Awangarda u schyłku XX wieku, przeł. M. Borowski, M. Sugiera, Universitas, Kraków 2010, s. 237.

5 Tamże, s. 12.

6 Tamżes. 56. 
twórczego krytyka). Jak i w wymiarze szczegółowym, pozwalającym zobaczyć w postmodernizmie myśl (czy raczej splot myśli) w nie mniejszym stopniu zaangażowaną w życie współczesnego świata niż posthumanizm. Jednak tym, co znacząco utrudnia przeprowadzenie dowodzenia, może być, twierdzi Huyssen, skomplikowana identyfikacja wspomnianych możliwości. Ponieważ nie zamierzam poprzestawać na powtarzających się w opisach postmodernizmu niepewnych założeniach ${ }^{7}$, przypomnę w skrócie, czym jest postmodernizowanie Zagłady i w jaki sposób chciałabym je łączyć $\mathrm{z}$ wartościowaniem.

W latach 6o. ubiegłego wieku, wraz z publikacją Pierwszej świetności Leopolda Buczkowskiego, zarysowała się idea zupełnie innego niż dokumentarne przedstawiania Zagłady w literaturze polskiej. Miała ona pokazać, że dokument nie jest jedyną formą opowiadania o prawdzie historycznej, a prawda historyczna nie musi być ostateczną instancją prawdy jako takiej. Nietrudno sobie wyobrazić, że owa idea nie zyskała w Polsce wielu zwolenników, mimo że w literaturoznawstwie anglojęzycznym doprowadziła do powstania tak wybitnych opracowań, jak Historiographic Metafiction: Parody and the Intertextuality of History Lindy Hutcheon czy Sublime Desire: History and Post-196os Fiction Amy J. Elias. Postmodernizowanie Zagłady oznacza kilka offowych i luźno powiązanych ze sobą praktyk, takich jak wymazywanie i odsłanianie historii, upolitycznienie miejsca, z którego mówi pisarz (powinno ono być mało znaczące i widoczne bądź tworzyć pogardzaną przez innych (o)pozycję), sprzeciw wobec czysto estetycznego rozumienia sztuki, krytyczno-polityczny charakter opowieści, zaprzeczających neokonserwatyzmowi, namysł nad spuścizną modernizmu etc. W Polsce tego typu problemy formułowali Buczkowski, Anatol Ulman, Andrzej Kuśniewicz, Tadeusz Konwicki, Ewa Kuryluk, Marek Bieńczyk, Magdalena Tulli czy Andrzej Bart. Ponieważ jest to dziś domykający się projekt, można pomyśleć o oderwaniu go od tradycyjnej historii literatury. Dlatego wspomnianych pisarzy powinno się zestawiać z eksperymentującymi twórcami angielskimi, amerykańskimi czy francuskimi, takimi jak Raymond Ferderman, Walter Abish, Jonathan Safran Foer, Nicole Krauss, Paul Auster i inni, a ich prozę analizować w pewnych pasmach równoznacznych z dekadami, które przyjmują przede wszystkim postać opowieści o zmieniającym się postmodernizmie i jego

7 Omawiają je: R. Nycz Tekstowy świat. Poststrukturalizm a wiedza o literaturze, Universitas, Kraków 2000, s. 161-171; B. Baran Postmodernizm i końce wieku, inter esse, Kraków 2003, s. 155-190; B. McHale Powieść postmodernistyczna, przeł. M. Płaza, Universitas, Kraków 2012, s. 3-8. 
wpływie na społeczeństwo i państwo. W ten sposób opisywali go Foster, Huyssen czy Grzegorz Dziamski ${ }^{8}$.

Projekt, który roboczo nazywam „postmodernizowaniem Zagłady”, nie wyczerpuje się na opisie literatury w kolejnych latach. Chodzi w nim także o zrozumienie, dlaczego kilka polskich powieści nie zwróciło przez lata niczyjej uwagi i jak bardzo zmienia się ich ocena, gdy zobaczy się je w otoczeniu mocnej ideowo zagranicznej prozy z tego samego dziesięciolecia. Pokazanie polskiej literatury jako części literatury światowej radykalnie zmienia jej wartościowanie (np. powieść Ulmana, interpretowana wspólnie z prozą Federmana czy Georges'a Pereca, pozwala docenić w niej ideę sous rature czy dojrzeć wartość logicznych przesunięć w obszarze mówienia o historii). Ale też przywraca sprawczość postmodernizmowi, czyniąc go nurtem, w który włączają się dzieła sztuki wywrotowe, ale często stanowiące kłopot dla krytyki lub w ogóle pozbawione ocen i niezrozumiałe bez orientacji w rozwoju sztuki awangardowej czy neoawangardowej. Na przykład stworzenie sieci wpływów i powiązań między prozą lat 8o. Waltera Abisha (Jakie to niemieckie) czy D.M.Thomasa (Biaty hotel) z jednej strony a niedocenianym Nawróceniem Kuśniewicza pozwala zobaczyć krytykę różnych form upamiętniania przeszłości wraz z toczącym się wówczas procesem Historikerstreit czy namysł nad nacjonalizmem i antysemityzmem w literaturze polskiej. Jeszcze inną zaletą stworzenia takiej sieci jest zainicjowanie w polskiej literaturze nurtu, którego nigdy w niej nie było, co wydaje się dzisiaj jak najbardziej możliwe i zgodne z ideą Nachträglichkeit.

Wartościowanie, mówi Foster, stanowi absolutnie podstawową czynność każdego, kto tworzy i pisze. Zależy także od „patosu dystansu”, który dla Fryderyka Nietzschego był równoznaczny z przejawianą przez krytyków skłonnością do szlachetnych intencji i podłego resentymentu' . Skoro nie da się uciec od wartościowania, można przynajmniej poluzować pewne kategorie i uczynić je użytecznymi. Użyteczne wartościowanie jest, jak sądzę, niezbędne do napisania krytycznego studium postmodernizmu. Ono samo z kolei wynika z oczywistych przesłanek, o których przypomina Ewa Domańska: „polskie środowisko historyczne nie przeszło dyskusji na temat postmodernistycznej krytyki historii"10.

8 G. Dziamski Postmodernizm wobec kryzysu estetyki współczesnej, Wydawnictwo Naukowe UAM, Poznań 1996, s. 105-128.

9 H. Foster Powrót Realnego..., s. 267-268.

10 E. Domańska Historia egzystencjalna. Krytyczne studium narratywizmu i humanistyki zaangażowanej, PWN, Warszawa 2012, s. 21. 
Zimno Piotra Czakańskiego wydaje się idealnym pretekstem do namysłu nad zmianą, jaka nastąpiła w postmodernizmie po 2000 roku i oddziałała na wartościowanie polskich postmodernistycznych powieści o Zagładzie ${ }^{11}$. Ponieważ oba te zjawiska są bardzo zniuansowane z jednej strony i mało popularne z drugiej, nie należy zakładać, że proza Czakańskiego cokolwiek zyska na włączeniu jej do opisywanych badań. Wartościowania nie definiuję dosłownie jako „szybkiego zysku”, zakładam raczej, że istotne okaże się w tym wypadku chociażby osłabienie działania takich jak ten komentarzy:

Umieszczone wśród tych utworów Zimno ujawnia wszakże swoją odmienność, a mianowicie ukazuje, że Zagłada objęła także nie-Żydów, że w pewnych przypadkach inni też podzielili ten sam los, który podobnie po latach poraża kolejne pokolenia swą wyjątkowością. Odbiegająca od postpamięciowych narracji jest, wprowadzona w zakończeniu powieści, chrześcijańska eschatologia, która stanowi pozytywną perspektywę wobec toposu holocaustowej literatury, jakim jest wygnanie z (opartego na biblijnych obrazach) mitu i osadzenie w dramacie historii. ${ }^{12}$

W literaturze amerykańskiej, która może stanowić naturalny kontekst Zimna, lata dwutysięczne zapisały się przede wszystkim jako czas reakcji na zamachy z 11 września 2001 roku. To właśnie wydarzenie nadało ton późniejszym opowieściom, także tym o Zagładzie, sprawiając, że spadła ona z wyjątkowej pozycji i stała się częścią postkolonialnych narracji o terroryzmie o charakterze synchronicznym, a nie hierarchicznym czy wyraźnie pozycjonującym wspomniane wydarzenia (tak byłoby np. w Historii miłości Nicole Krauss, odwołującej się do skutków pogromu w Jedwabnem, a pośrednio do zdarzeń z 2001 roku). Niehierarchiczność w przedstawianiu masakr jest również cechą prozy Jonathana Safrana Foera, z którego powieścią Wszystko jest iluminacją z 2002 roku warto porównać Zimno.

Foer opowiada losy amerykańskiego Żyda poszukującego na terenach dzisiejszej Ukrainy ludzi, którzy uratowali jego przodków przed Zagładą.

11 Idealną przede wszystkim dlatego, że powieść przeszła prawie zupełnie bez echa, nie napisano o niej poza dwoma wyjątkami żadnych szkiców czy recenzji, a w opinii środowiska "FA-artu”, z którego wywodzi się autor Zimna , "taki byt jak pisarz Piotr Czakański-Sporek nie istnieje" (wypowiedź Dariusza Nowackiego sformułowana w rozmowie prywatnej).

12 B. Gontarz Obrazy świata. Wizualne reprezentacje rzeczywistości w polskiej prozie współczesnej, Wydawnictwo UŚ, Katowice 2014, S. 132. 
Czyni to jednak w bardzo przewrotny sposób, za pomocą dwu równoległych narracji, z których pierwsza dotyczy poszukiwań, a druga opowiada dzieje pewnej żydowskiej diaspory od XVIII wieku po współczesność. W jednym z epizodów ukraińscy Żydzi ratują z wypadku (powóz z ciężarną wpadł do rzeki) noworodka. A właściwie dziecko, które urodziło się w wyniku wstrząsu i pod wpływem śmierci matki. Jest to historia tyleż nieprawdopodobna i okrutna, co symboliczna i w jakimś sensie zapowiadająca losy całego dziesięciolecia, z którego pochodzi książka Foera. Wydaje się bowiem, że metafora nadnaturalnych narodzin stanowi przede wszystkim signum temporis i oddaje charakter narracji o Zagładzie w latach dwutysięcznych. W pierwszej kolejności ich pokoleniowy i ściśle związany z Zagładą charakter (Foer i Krauss są przedstawicielami trzeciego pokolenia, a ich przodkowie urodzili się przed wojną w Polsce, na Białorusi i Ukrainie). W drugiej, odsyłającej do filozofii postmodernizmu lat dwutysięcznych, a nie tylko literaturoznawstwa, powieści z tego okresu układają się w wielką abiektalną wypowiedź o rzeczywistości, w której wiodąca rola przypadła właśnie Czakańskiemu.

Próbując zrozumieć przyczyny fascynacji traumą i zazdrością o abiekt, Foster zauważył, że poststrukturalistyczny postmodernizm wyparł Realne, które następnie powróciło jako Realne traumatyczne. Sądzę, że ów powrót stał się możliwy przede wszystkim wskutek refleksji filozoficznej, społecznej i politycznej, która zawiązała się wokół wydarzeń z lat 2000-2001, w sposób jednoznaczny przekreślających obowiązującą wcześniej - i pewnie nie jedyną - ideologię realizmu. W części zatytułowanej Realizm, pochodzącej z artykułu Odpowiedź na pytanie: co to jest postmodernizm? opublikowanego w 1986 roku, Jean-François Lyotard przyjął, że realizm lat 8o. powstał w wyniku "likwidacji dziedzictwa awangard”13 i stał się częścią „zamiaru uniknięcia problemów z rzeczywistością" ${ }^{4}$, zmieniając się w styl ograniczony z jednej strony akademizmem, z drugiej kiczem. ,Gdy władza staje się partią, realizm i jego neoklasycystyczne uzupełnienie triumfują nad eksperymentatorską awangardą, szkalując ją i odmawiając jej racji istnienia. Konieczne jest także, by «słuszne» obrazy, «słuszne» opowiadania, poprawne formy powoływane do istnienia, wybierane i rozpowszechniane przez partię, znalazły publiczność, która potrzebowałaby ich jako właściwego lekarstwa na lęk i depresję"15.

13 J.-F. Lyotard Odpowiedźna pytanie: co to jest postmodernizm?, przeł. M.P. Markowski, w: Postmodernizm. Antologia przekładów..., s. 50.

14 Tamże, s. 52.

15 Tamżes. 52-53. 
Niewątpliwą zasługą postmodernizmu jest demontaż silnego, faszystowskiego podmiotu, a więc takiego, który z jednej strony próbuje przejąć władzę, a z drugiej - radykalnie eliminuje wszelką obcość. Warto zwrócić uwagę, że teoretycy tacy jak Foster czy Huyssen poszukują negatywnej tradycji dla postmodernizmu w postaci ustanowienia kanonu myśli modernistycznej w latach 40. i 50. XX wieku ${ }^{16}$. Otwiera to szerokie pole dla wielu różnych przewartościowań, które mogą pomóc w stworzeniu ideowych ram dla postmodernizowania Zagłady i ułatwić bliższe przyjrzenie się jednym tradycjom modernistycznym (Foster proponuje wziąć pod uwagę Lacana) i odrzucić inne, mniej przydatne.

Tradycją niezwykle ważną, jak się okazuje, także dla samego Czakańskiego, jest myślenie o rzeczywistości w kategoriach rany z całym zapleczem teoretycznym pojęcia realizmu traumatycznego ${ }^{17}$. Kategoria traumy nie wydaje się szczególnie popularna wśród piszących o Zagładzie postmodernistów, narzuca bowiem zachowania ograniczające krytykę różnych polityk i języków. Gdy się już pojawia, to raczej jako okazja do wolty i kontry niż zaproszenie do wspierającego opisu czy akceptacji ${ }^{18}$. W przypadku Zimna i Wszystko jest iluminacja mamy jednak do czynienia z sytuacją makabrycznie rozumianej rany, która z jednej strony oznacza gwałtowny i nienaturalny poród, a z drugiej - okaleczony, sierocy podmiot, który staje się dość nietypowym świadkiem wszystkiego, czego później doświadcza. „Jeśli istnieje podmiot historii w kulcie abiektalności, nie jest nim z pewnością Robotnik, Kobieta czy Kolorowy, lecz Martwe Ciało. To nie tylko polityka różnicy, która przerodziła się w obojętność; to także polityka inności sięgająca nicości [...]. Czy abiektalność to gest odrzucenia władzy, jej nadużycia czy też wymyślenia na nowo? I wreszcie, czy abiektalność to czasoprzestrzeń poza zbawieniem, czy też najszybsza droga do zbawienia dla współczesnych upadłych świętych"19.

16 Huyssen twierdzi np., że „to właśnie epoka Hitlera, Stalina i zimnej wojny wydała szczególne ujęcia modernizmu, jak np. te autorstwa Clementa Greenberga i Adorna". Cyt. za: A. Huyssen Nad mapq postmodernizmu..., s. 483.

17 Por. przede wszystkim: M. Rothberg Traumatic realism. The Demands of Holocaust Representation, University of Minnesota Press, Minneapolis-London 2000.

18 Por. .. Hirsch Postmodernizm, drugie pokolenie i międzykulturowe kino posttraumatyczne, przeł. T. Bilczewski, A. Kowalcze-Pawlik, w: Antologia studiów nad traumq, red. T. Łysak, przeł. T. Bilczewski, K. Bojarska, J. Burzyński, A. Kowalcze-Pawlik, A. Rejniak-Majewska, Universitas, Kraków 2015, S. 253-284. 
Podstawą powieści Czakańskiego są dość dobrze znane fakty z życia mieszkańców Markowej, Marii i Józefa Ulmów, którzy 24 marca 1944 roku zginęli z rąk Polaków za ukrywanie Żydów. Czakański pisze o tym w pierwszym rozdziale zatytułowanym Kwiecień, ale od razu dodaje coś od siebie, korzysta bowiem z narracji pierwszoosobowej. Kto za nią stoi? Siódme dziecko Ulmów, którego nie było w historii, sześciopalczasty Zygmunt, pod sutanną wyniesiony z grobu przez proboszcza. Narracja układa się niemal od razu w wyznania jakiegoś monstrum, pogrobowca czy żywego trupa i wraz z rozwojem akcji odsłania jeszcze więcej dziwactw - osobliwą samotność bohatera, adopcję, chorobę terminalną (Chronic Lymphocytic Leukemia), tragiczną śmierć lekarza, który może zdołałby opóźnić jej rozwój, i wreszcie perwersyjny katolicyzm ostatniego Ulmy. A wszystko to staje się o wiele ważniejsze od samej Zagłady, pozostawionej w pierwszym rozdziale w charakterze koniecznego, ale nie najlepszego punktu wyjścia. Czakański nie decyduje się pójść tropem historyków, Dariusza Libionki i Jana Grabowskiego, którzy w 2016 roku ujawnili, że w tym samym czasie, kiedy zabito Ulmów i ukrywane przez nich żydowskie rodziny, w okolicy dokonano wielu znacznie bardziej brutalnych mordów na Żydach ${ }^{20}$. Poprzestaje natomiast na świeżych i nielicznych w 2006 roku opracowaniach Józefa Szarka i Mateusza Szpytmy²1. Wysupłuje z nich przejmującą historię zamordowania sześciorga Polaków opisaną przez nowo narodzone dziecko, które przetrwało rzeź w grobie. Od stwierdzenia tego faktu do przyznania, że Zimno jest psychotyczną fantazją polskiego pisarza na temat traumy, jaką polskie społeczeństwo przeżyło w związku z Zagładą, dzieli nas niewiele. Aby jeszcze zmniejszyć ten dystans, dodam, że jest to prawdopodobnie strategia założona przez samego pisarza. Po pierwsze, w kilku miejscach powieści puszcza wodze fantazji i wyobraża sobie, co by było, gdyby matka Zygmunta żyła współcześnie i była szykanowana z powodu wielu ciąż; co gdyby sąsiad Marii i Józefa zamiast Shlomo nazywał się Abraham (to sugestia, że opowieść o ocaleniu z grobu ma znamiona historii świętej) etc. Po drugie, powieść kończy się podpisem "Maishofen 2006", odsyłający do nazwy austriackiego miasteczka, w którym częściowo rozegrała się akcja kilku rozdziałów. Czemu to wszystko miałoby

20 J. Grabowski, D. Libionka Bezdroża polityki historycznej. Wokół Markowej, czyli o czym nie mówi Muzeum Polaków Ratujq̨cych Żydów podczas II Wojny Światowej im. Rodziny Ulmów , Zagłada Żydów. Studia i Materiały" 2016 nr 12, s. 619-642.

21 Ofiara Sprawiedliwych. Rodzina Ulmów - oddaliżycie za ratowanieżydów, Dom Wydawniczy „Rafael", Kraków 2004. 
służyć? Przesunięciu akcentów z Zagłady na nieprawdopodobną traumę rzekomego polskiego świadka, której nie sposób zakwestionować, choć można w nią nie uwierzyćc $c^{22}$.

Przekierowanie uwagi i przeniesienie punktów ciężkości osiąga autor Ostatniej amerykańskiej powieści dzięki przekroczeniu granic empatii ${ }^{23}$, zarezerwowanej właściwie tylko dla osób o zbliżonym doświadczeniu, np. Żydów, którzy ucierpieli w prześladowaniach i polowaniach wokół Markowej, opisanych przez Libionkę i Grabowskiego. Oparte na negatywnych afektach, takich jak złość czy nienawiść, przekroczenie prowadzi bohatera w kierunku coraz bardziej ahistorycznej identyfikacji z Żydami. Jej moment krytyczny stanowi upodobnienie austriackich tartaków, których właścicielem stał się Zygmunt jako dorosły człowiek, do firmy Citroëna:

gdy dowiedziałem się z artykułu w codziennej gazecie, że to polski Żyd jest twórcą citroenów, nabrałem chęci do przyjrzenia się tym samochodom. I tak, z czasem, tylko citroëny jeździły w mojej firmie. Sam pan Citroën był dla mnie nie lada odkryciem. Zarządzałem firmą, stosując wymyślone przez niego metody.Tak jak on, postanowiłem nie mieć na własność domu czy mieszkania. Pieniądze były w firmie i ludziach. Nie szczędziłem na inwestycje w technologie. Wszystko i wszyscy mieli działać. Precyzyjna robota stała się naszym znakiem firmowym. $(\mathrm{Z}, 60)$

$\mathrm{Z}$ „niepełnego świadka” Zagłady ${ }^{24} \mathrm{i}$ „podmiotu traumatycznego”25 bohater Zimna staje się kapitalistą o przeciętnej umysłowości i ograniczonych oczekiwaniach wobec świata. Jego główne zainteresowania dotyczą rynków zbytu, banków, przelewów i zabezpieczania sobie przyszłości za pomocą pieniędzy. To trudne do zrozumienia przejście od opisu traumy polskiego świadka do euforii austriackiego kapitalisty nie czyni jednak historii Ulmów obiektem manipulacji. Jest to raczej częsty we współczesnej prozie przykład wchodzenia w nie swoje buty, czyli fantazja współczesnego polskiego pisarza podszywającego się pod obserwatora, postronnego

H. Foster Powrót Realnego...,s. 197.

A. Łebkowska Empatia. O literackich narracjach przełomu XX i XXI wieku, Universitas, Kraków 2008, s. 85-104.

Tamże.

Tamże. 
czy gapia Zagłady ${ }^{26}$. Czakański uczynił swoją abiektalną wypowiedź formą sięgnięcia po nową władzę, jaką dał mu połączony z kapitalizmem polski katolicyzm w zaściankowej wersji, ograniczonej do kultu dewocjonaliów („A może by tak pochować mnie z obrazeczkiem Heil. Maria zu Piekar? Z, 74 ${ }^{27}$ ).

W ostatniej scenie, będącej narcystycznym wariantem wspomnianej fantazji, bohater planuje swój pogrzeb. Ale planuje go nie w sposób ogólny, a chorobliwie szczegółowy. Można powiedzieć, że dopracował każdy detal: od początku umierania po zarośnięcie grobu trawą. Jaką perwersję w ten sposób zaspokaja?

Umieranie zacznę od zawieszenia akwareli Matka i dziecko sygnowanej S. 10 przez dwudziestoletniego artystę. Znowu będzie marzec i ledwie co zadomowi się tysiąc dziewięćset czterdziesty czwarty... zastygająca mamusia, lód w kałużach będzie trzaskał pod naporem kopyt szarych koni, zacznę bieg przez rozmokłe pole, powróci męcząca świadomość zakazu płaczu, będę słyszał głuche słowa szczerej modlitwy różańcowej, intonowanej przez wieśniaków za spokój duszy wymordowanych rodzin. $(\mathrm{Z}, 74)$

Perwersję bycia małym, żydowskim chłopcem, który biegnie opłotkami Markowej, by się ukrywać. Potwierdza tę intuicję ostatnie zdanie Zimna o modlitwie w intencji kilku rodzin (żydowskich). Byłaby to wskazówka, że Czakański zestraja narracyjną empatię z fantazjami o ukrywającym się dziecku, za którego los, nie wiedząc nic o tym, modlą się Polacy.

W przypadku Zimna mamy do czynienia z pastiszem różnych rodzajów narracji: „dorosłego niemowlęcia”, polskiego Sprawiedliwego, kapitalisty i Żyda. Ale także z pastiszem powieści Thomasa Bernharda Mróz (do którego odsyła motto). Gdy zna się nieco bardziej twórczość autora Pierrota i Arlekina i występujące w niej nawiązania do tradycji i kultury żydowskiej ${ }^{28}$, wolno

Na temat znaczenia tych kategorii por. m.in. K. Koprowska Postronni? Zagłada w relacjach chłopskich świadków, Universitas, Kraków 2018.

Dalej strony z powieści Zimno P. Sporka podaję za wydaniem: P. Czakański Zimno, FA-art, Katowice 2006, i oznaczam literą "Z".

A są to przede wszystkim pastisze, parodie i parafrazy prozy Franza Kafki (Ostatnia powieść amerykańska jest pastiszem Ameryki Franza Kafki, w Pierrocie i Arlekinie można z kolei znaleźć nawiązania do wojennego epizodu w biografii Karla Jaspersa i jego żony Żydówki. Ważne wydaje się także opowiadanie Mówiq̨c tak między nami... opublikowane w „FA-arcie”, a będące rozmową postaci, której pisarz użyczył swojego imienia i nazwiska, z wujem-rabinem. Rozmowa, co istotne, toczy się na katowickim cmentarzu żydowskim przy ul. Kozielskiej 16. 
stwierdzić, że Zimno jest zaskakującą prowokacją, a nie psychotyczną narracją filosemity. Jej potencjał krytyczny polega przede wszystkim na rozbrojeniu podmiotu faszystowskiego i ustanowieniu Zagłady punktem wyjścia dla rozległej analizy różnych dewiacji: od mechanizmów projekcji i identyfikacji, związanych z fantazjowaniem przez pisarzy o udziale w II wojnie światowej w charakterze obserwatorów i świadków, po kiczowaty nadmiar nieszczęść, odsyłających do kalectwa i kultury rany.

Postmodernizm połowy lat dwutysięcznych zaproponował krytykę państwa, Kościoła i kapitalizmu. Uczynił to jednak za pomocą kilku, słabo widocznych narracji, które zdegradowano do postaci wypowiedzi banalnych bądź nieudanych (casus Fabryki muchołapek Barta). Tym samym temu, co Foster nazwał „zemstą filistynów”, „wulgarnym kiczem medialnych sprzedawców” i "nowym barbarzyństwem”29, nie tylko nie przywrócono społecznej użyteczności. Dyskusję nad krytycznymi możliwościami postmodernizmu zatrzaśnięto niczym wieko fortepianu. Realizm postmodernistyczny, który wyeliminował estetykę niewyrażalności kilkanaście lat temu, stał się projektem rozpoznanym powierzchownie, zarzuconym, zmarnowanym. Należałoby wrócić do jego podstaw, takich jak hiperrealizm czy krytyka chorobliwych zachowań społecznych, którą proponowały opowieści sprzed ponad dekady, aby z powrotem wprawić w ruch zatrzymaną dyskusję i ujrzeć użyteczność niektórych jej aspektów, uznanych za szkodliwe w pośpiesznym, niedbałym wartościowaniu. Celem tego powrotu byłoby rozważenie krytycznych i politycznych możliwości postmodernizmu, których mu odmówiono przed ostatecznym bilansem.

Jak pisał Ryszard Nycz: „głównymi obiektami postmodernistycznej krytyki [...] były: wąsko pojęte («scjentystyczne») kryteria racjonalności; koncepcja autonomicznej, obiektywnej nauki oddzielonej zarówno od polityki jak od moralności; naczelne idee (jedności, całości, systemowości); powszechnie obowiązujące kryteria (jak prawda, rozum, sprawiedliwość, obiektywność, uniwersalność)" ${ }^{\text {30. W }}$ We stabilne fundamenty uderzył także Gross, dając początek krytycznemu nurtowi postmodernizmu realistycznego oraz narracjom, których oddziaływanie społeczne należałoby jednak dopiero reaktywować.

H. Foster Powrót Realnego..., s. 236. 


\section{Abstract}

\section{Marta Tomczok}

UNIVERSITY OF SILESIA (KATOWICE)

Postmodern Realism, the Abject, Valuation: The Benefits of Critically Reflecting on Postmodernism and the Holocaust

Building on theories of postmodernism by Andreas Huyssen, Ryszard Nycz, and especially Hal Foster, Tomczok introduces the notion of realistic postmodernism to describe conceptual and aesthetic practices used in the new millennium. One tipping point is the publication of the Polish edition of Jan T. Gross's Neighbours; Tomczok links the cultural shift it provoked with the rapid departure from debates on postmodernism as such. (In other literatures this tipping point falls to 11 September 2001). Her goal is to highlight the benefits of a return to the debate on Polish postmodernism in the context of the Holocaust. This is why she introduces another notion, namely that of postmodernising the Shoah. It relates to postmodern fictional representations of the Holocaust, which in the 2000s took the shape of socially engaged narratives, critiquing late modernity and capitalism.

\section{Keywords}

postmodern realism, postmodernising the Shoah, Piotr Czakański, Catholicism, capitalism 